\title{
Cooperative Regulation of Neurotensin Content in PC12 Pheochromocytoma Cell Cultures: Effects of Nerve Growth Factor, Dexamethasone, and Activators of Adenylate Cyclase
}

\author{
Arthur S. Tischler, ${ }^{*}$ Ying C. Lee,† Donna Costopoulos, ${ }^{*}$ Val W. Slayton, ${ }^{*}$ \\ William J. Jason, ${ }^{*}$ and Stephen R. Bloom $\dagger$ \\ *Department of Pathology, Tufts University School of Medicine, Boston, Massachusetts 02111, and †Department \\ of Medicine, Royal Postgraduate Medical School, Hammersmith Hospital, London, W12OHS, England
}

\begin{abstract}
Nerve growth factor, dexamethasone, and forskolin or cholera toxin (CT) act cooperatively to increase the content of neurotensin (NT) in PC12 pheochromocytoma cells. Relatively small increases in NT content occur in the presence of NGF alone or dexamethasone alone, but not of forskolin or CT alone. Increases of 10- to 100 -fold occur in the presence of NGF plus dexamethasone or NGF plus forskolin, and up to $\mathbf{6 0 0}$-fold increases occur in the presence of all three agents. These increases are extremely stable and persist for at least 2 weeks after removal of dexamethasone or forskolin. The complex regulation of NT stores in PC12 cells might reflect mechanisms that regulate NT content of normal chromaffin cells and/or neurons during development or in adult life. A small amount of stored NT is released in response to stimulation with $52 \mathrm{mM} \mathrm{K} \mathrm{K}^{+}$. This release is blocked in the presence of $2 \mathrm{mM} \mathrm{Co}^{2+}$, suggesting that it occurs via $\mathrm{Ca}^{2+}$-mediated exocytosis.
\end{abstract}

Neurotensin (NT) is a tridecapeptide present in a variety of neurons and neuroendocrine cells of mammals and other vertebrates (Carraway and Leeman, 1973; Leeman and Carraway, 1982; Terenghi et al., 1982). In the rat, immunoreactive NT has been demonstrated in the brain and spinal cord (Polak and Bloom, 1982), in endocrine cells of the enteric mucosa (Polak and Bloom, 1982; Sundler et al., 1982), in norepinephrine (NE)containing chromaffin cells of the adrenal medulla (Goedert et al., 1983; Rokaeus et al., 1982, 1984), and in occasional nerve fibers in the myenteric plexus (Schultzberg et al., 1980). The physiology of NT is incompletely understood. Mechanisms that regulate its storage and release in different locations remain unclear. Its reported biological activities include excitatory and inhibitory neurotransmission (Henry, 1982), excitation and contraction of intestinal smooth muscle, vasodilation, increased vascular permeability, and increased secretion of pituitary hormones (Leeman and Carraway, 1982).

We have recently reported that NT is produced, stored, and released by PC12 pheochromocytoma cells in vitro (Tischler et al., 1982a, 1983b). PC.12 cells are a clone of NE- and dopamine (DA)-producing chromaffin-like cells (Greene and Tischler, 1976, 1982) derived from a rat adrenal medullary tumor (Warren and Chute, 1972). Because of their similarities to normal NE cells, PC12 cells might serve as an experimental model with which to study mechanisms that regulate NT levels in the normal

Received July 19, 1985; revised Oct. 21, 1985; accepted Oct. 23, 1985

Supported by NIH Grant CA 27808 and by the Medical Research Council. The authors thank Dr. Robert Perlman for comments on the manuscript and Mrs. Carol Ostrum for secretarial assistance.

Correspondence should be addressed to Dr. Tischler, Department of Pathology, Tufts University School of Medicine, 136 Harrison Avenue, Boston, MA 02111. Copyright @ 1986 Society for Neuroscicnce 0270-6474/86/061719-07\$02.00/0 adrenal gland. Information derived from such studies might also provide insights into the physiology of other types of NT-containing neural and neuroendocrine cells. In previous studies, we have found that dexamethasone and NGF act synergistically to increase the content of NT in PC12 cells (Tischler et al., 1983a, b). This increased cellular content of NT is accompanied by increased concentrations in the culture medium, indicating that the increased cellular stores reflect increased production, rather than decreased turnover of NT (Tischler et al., 1983a). In the present investigation, we have studied the regulation of NT content in PC12 in cells in greater detail, and we have observed that activators of adenylate cyclase provide an additional means of regulation.

\section{Materials and Methods}

\section{Cell culture methods}

Stock cultures of $\mathrm{PC} 12$ cells (passages 27-37) were grown routinely on $100 \mathrm{~mm}$ polystyrene tissue culture dishes (Falcon Laboware, Div. Becton-Dickinson, Oxnard, CA) in RPM1 1640 medium (Gibco, Grand Island, NY) with $10 \%$ heat-inactivated horse serum (K. C. Biologicals, Lenexa, KS), $5 \%$ fetal bovine serum (Hyclone, Inc.), $50 \mathrm{mg} / \mathrm{ml}$ streptomycin, and $50 \mathrm{U} \mathrm{ml} \mathrm{penicillin} \mathrm{(Gibco).} \mathrm{For} \mathrm{each} \mathrm{experiment,} \mathrm{cells} \mathrm{in}$ fresh medium were scraped from near-confluent stock dishes with a rubber policeman and plated on $60 \mathrm{~mm}$ Falcon dishes coated with airdried rat tail collagen (Bornstein, 1958). Some experiments were also performed with cells grown in vivo as solid tumors (Greene and Tischler, 1976). Each dish was inoculated with $10^{6}$ cells. Unless otherwise specified, experimental cultures were maintained in the routine growth medium described above. For experiments in serum-free medium, cultures were initially plated in complete medium without other additives in order to permit cell attachment. They were then washed and transferred to medium that was identical except for the omission of serum, and the indicated experimental additions were made. Stock cultures and experimental cultures were maintained $37^{\circ} \mathrm{C}$ in a water-saturated atmosphere of $93 \%$ air and $7 \% \mathrm{CO}_{2}$. The medium was changed $3 \times$ per week.

\section{NT content}

Experiments were performed to measure changes in NT content in response to treatment for up to 4 weeks with various concentrations of dexamethasone disodium phosphate (a gift from Merck Sharp \& Dohme Research Laboratories, West Point, PA), 2.5 S mouse salivary gland NGF [prepared by the method of Mobley et al. (1976)], forskolin (Calbiochem), and cholera toxin (CT; Boehringer-Mannheim). In some experiments, cells were pretreated for $10 \mathrm{~d}$ with $1 \mu \mathrm{M}$ cytosine arabinoside (AraC; Sigma Chemical Co., St. Louis) to prevent replication (Greene and Rein, 1976). To study the reversibility of the effects of dexamethasone and forskolin, cultures treated for 2 weeks with optimal concentrations of NGF plus dexamethasone or NGF plus dexamethasone plus forskolin were washed $3 \times$ in medium with no additives, switched to medium with NGF alone or NGF plus dexamethasone, respectively, and maintained for up to 2 additional weeks. 


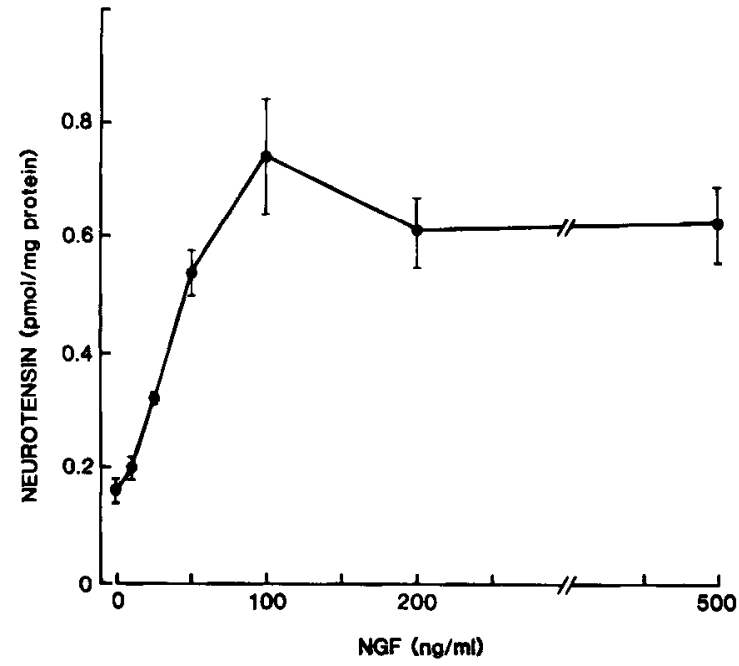

Figure 1. Dose-response curve for effects of NGF on NT content in the presence of dexamethasone $(1 \mu \mathrm{M})$. Cultures were maintained for $14 \mathrm{~d}$ before harvest. Values represent means \pm SEM of three dishes.

\section{NT secretion}

To study stimulated secretion of NT, cultures were maintained for 2 weeks with optimal concentrations of NGF plus dexamethasone. They were then washed twice in a "releasing medium" consisting of KrebsRinger HEPES buffer, pH 7.3 (Greene and Rein, 1976), with $0.5 \%$ heatinactiviated horse serum, and were preincubated at $37^{\circ} \mathrm{C}$ for $5 \mathrm{~min}$ in releasing medium alone or in releasing medium containing $2 \mathrm{mM} \mathrm{CoCl}_{2}$. Following this preincubation, they were incubated at $37^{\circ} \mathrm{C}$ for 15,30 , or $60 \mathrm{~min}$ in releasing medium containing $52 \mathrm{mM} \mathrm{KCl}$ or $100 \mathrm{nM}$ monensin in the presence or absence of $\mathrm{CoCl}_{2}$. Equal osmotic strength was maintained under the various incubation conditions by adjustment of the $\mathrm{NaCl}$ concentration in the releasing medium. Cells and releasing medium were harvested separately for NT assays.

\section{Assay methods}

To harvest cells for NT assays the culture medium or releasing medium was removed from each dish and the cells were washed $3 x$ in Hanks' balanced salt solution (Gibco). The cells were then scraped from the culture dishes in ice-cold, aprotinin-supplemented PBS, pH 7.2 (final aprotinin concentration, $500 \mathrm{KIU} / \mathrm{ml}$; Sigma), sonicated, and boiled for $5 \mathrm{~min}$. Aliquots were taken for protein determinations. The remainder of the sonicate was supplemented with radioimmunoassay grade BSA (final concentration, 1.5\%; Sigma), frozen, and lyophilized in a Speedvac concentrator (Savant Instruments, Farmingdale, MA). Protein was measured by Spector's modification (Spector, 1978) of the Bradford Coomassie blue method (Bradford, 1976). The releasing medium from each dish was collected in ice-cold tubes, supplemented with aprotinin (final concentration, $500 \mathrm{KIU} / \mathrm{ml}$ ), and centrifuged at $500 \times \mathrm{g}$ for $3 \mathrm{~min}$. Aliquots of $1.4 \mathrm{ml}$ were withdrawn from each tube, frozen, and lyophilized.

Lyophilized samples were reconstituted in distilled water, and NT content was determined by radioimmunoassay as previously described, using a rabbit antiserum against synthetic bovine NT (Lee et al., 1984). Samples of cell extract and medium from cultures treated for $5 \mathrm{~d}$ with NGF plus dexamethasone plus CT were also characterized by gel-permeation chromatography as previously described (Tischler et al., 1982a), using a Sephadex G-50 superfine column $(0.9 \times 60 \mathrm{~cm})$ calibrated with dextran blue, horse heart cytochrome $\mathrm{c}$, and $\mathrm{Na}{ }^{125} \mathrm{I}$ as molecular size markers. The column eluent was $0.06 \mathrm{~m}$ phosphate buffer, $\mathrm{pH} 7.0$, containing 0.3 BSA.

\section{Results}

NGF, dexamethasone, and activators of adenylate cyclase all act synergistically to produce increases in NT stores in PC12 cells in vitro. The absolute amount of NT per milligram of cell protein appears to vary with different batches of serum and/or medium. These variables also appear to affect the time courses

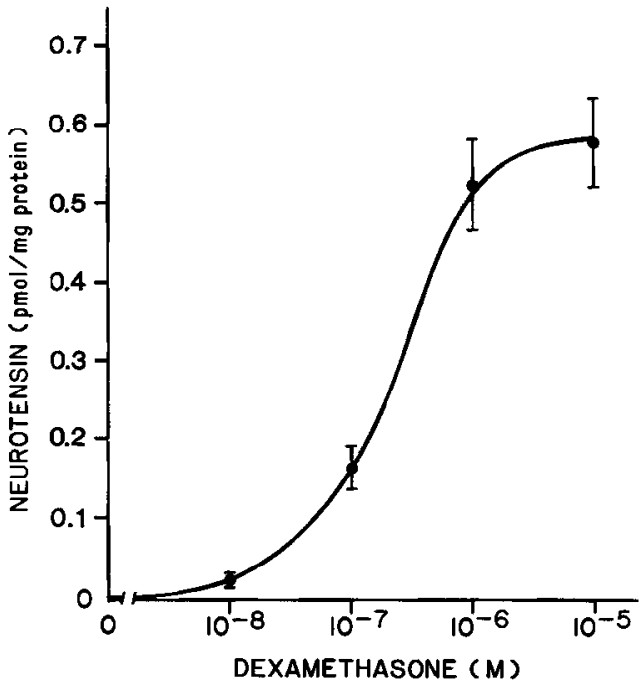

Figure 2. Dose-response curve for effects of dexamethasone on NT content in the presence of NGF $(200 \mathrm{ng} / \mathrm{ml})$. Cultures were maintained for $14 \mathrm{~d}$ before harvest. Values represent means \pm SEM of three dishes.

for the effects of specific additives. The relative changes produced by any given additive, however, are always consistent. In cultures maintained for 2 weeks in routine medium with $10 \%$ horse serum, $5 \%$ fetal bovine serum, and a saturating or nearsaturating concentration of dexamethasone, NGF causes a dosedependent 4- to 20-fold further increase in NT content. With the medium-changing schedule employed, this effect is detectable at NGF concentrations as low as $10 \mathrm{ng} / \mathrm{ml}$ and reaches a plateau at $50-100 \mathrm{ng} / \mathrm{ml}$ (Fig. 1). Similarly, in the presence of a saturating concentration of NGF, dexamethasone causes a 30to 50-fold further dose-dependent increase in NT content. This effect is detectable at dexamethasone concentrations as low as

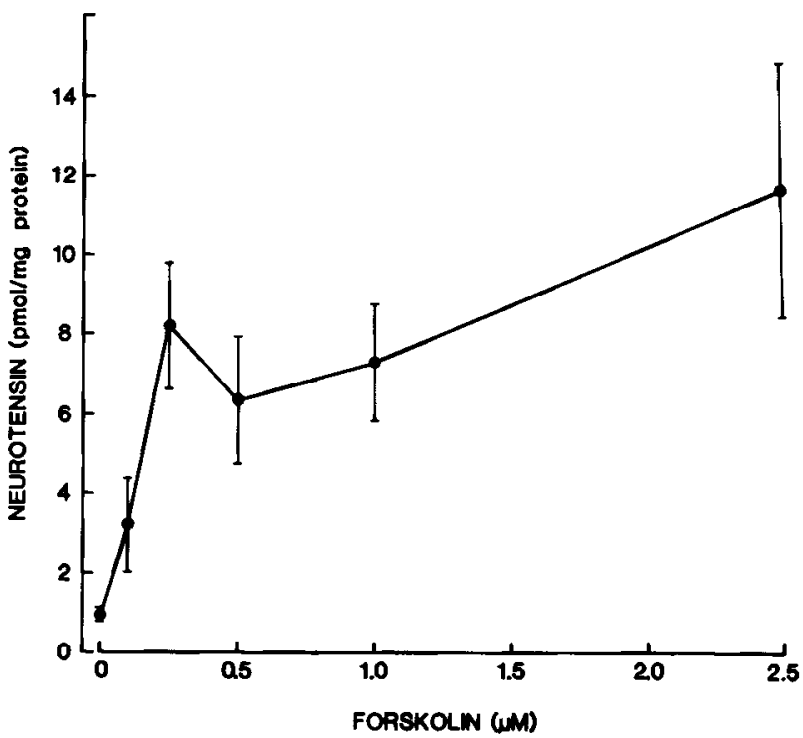

Figure 3. Dose-response curve for effects of forskolin on NT content in the presence of NGF $(200 \mathrm{ng} / \mathrm{ml})$ plus dexamethasone $(1 \mu \mathrm{M})$. Cultures were maintained for $14 \mathrm{~d}$ before harvest. There is no statistically significant difference between effects of 1.0 and $2.5 \mu \mathrm{M}$ forskolin $(p>0.05)$. Values represent means \pm SEM of three dishes. In other experiments, concentrations of forskolin $>1 \mu \mathrm{M}$ resulted in decreased NT content. Cells treated with $10 \mu \mathrm{M}$ forskolin in the presence of NGF plus dexamethasone contained approximately $40 \%$ as much NT as cultures treated with $1 \mu \mathrm{M}$ forskolin in the presence of NGF plus dexamethasone. 


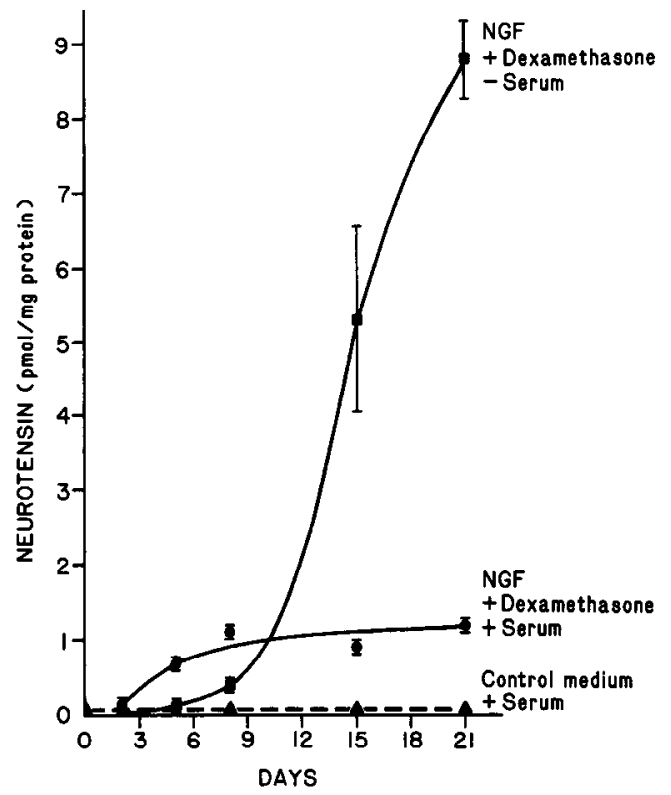

Figure 4. Time course for changes in NT content in cultures treated with NGF $(200 \mathrm{ng} / \mathrm{ml})$ plus dexamethasone $(1 \mu \mathrm{M})$ in serum-containing or serum-free medium. Values represent means \pm SEM of three dishes. In other experiments, differences between NT content of cells in serumcontaining and serum-free medium at 2 weeks varied between $2-5 \times$. The protein content of cells in serum-free cultures with NGF plus dexamethasone for 2 weeks is $90 \pm 10 \mu \mathrm{g} / 10^{6}$ cells vs. $117 \pm 4 \mu \mathrm{g} / 10^{6}$ cells in serum-containing medium (means $\pm \mathrm{SEM}, n=3$ ).

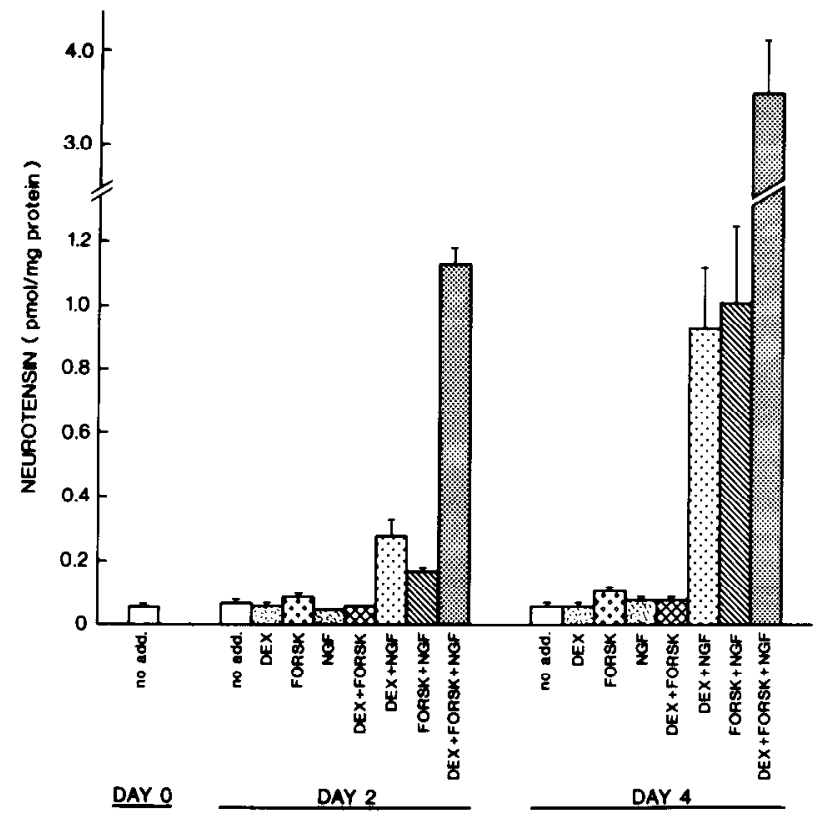

Figure 5. Early effects of dexamethasone $(1 \mu \mathrm{M})$, NGF $(200 \mathrm{ng} / \mathrm{ml})$, and forskolin $(1 \mu \mathrm{M})$ on content of NT. Identical patterns of responses were obtained in additional experiments containing cholera toxin $(1 \mu \mathrm{g} /$ $\mathrm{ml}$ ) in place of forskolin. Values represent means \pm SEM of three dishes. The chromatographic profile of immunoreactive NT in extracts of cells treated with dexamethasone plus cholera toxin plus NGF was identical to that previously reported in cultures treated with dexamethasone plus NGF (Tischler et al., 1982a) and consisted of a single peak co-eluting with synthetic NT applied to the column as a marker. Recovery was 69 vs. $76 \%$ for the NT standard (data not shown). Longer term cultures (14 d) show small increases in NT content in cells treated with dexamethasone alone or with NGF alone (Tischler et al., 1982a) but not with 1,5 , or $10 \mu \mathrm{M}$ forskolin alone.

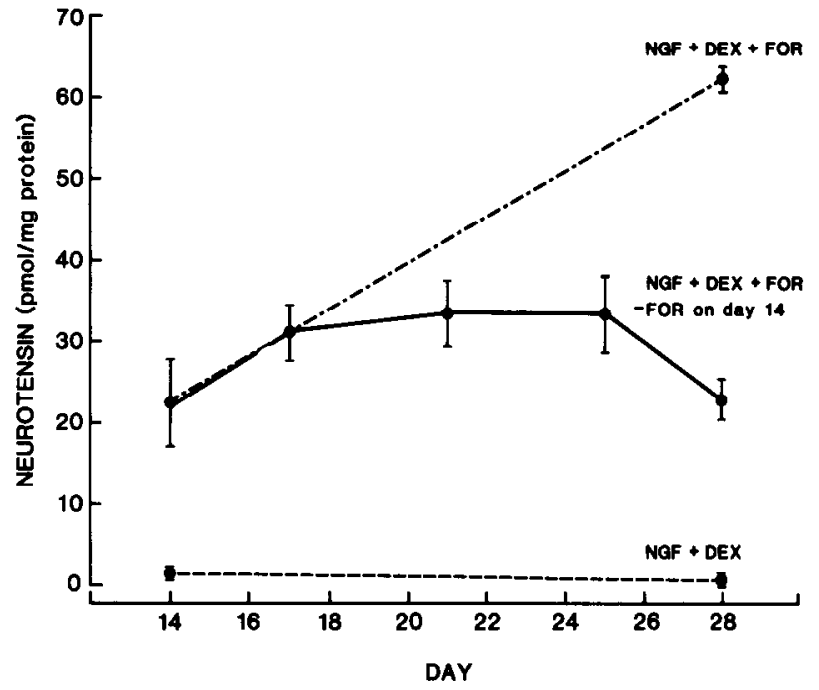

Figure 6. Effects of removing forskolin from cultures pretreated for $14 \mathrm{~d}$ with forskolin $(1 \mu \mathrm{M})$ plus dexamethasone $(1 \mu \mathrm{M})$ plus NGF (200 $\mathrm{ng} / \mathrm{ml}$ ). The content of NT $14 \mathrm{~d}$ after forskolin removal remains as high as at the time of removal. Values represent means \pm SEM of three dishes.

$10^{-8} \mathrm{M}$ and plateaus between $10^{-6}$ and $10^{-5} \mathrm{M}$ (Fig. 2). In the presence of saturating concentrations of NGF plus dexamethasone, up to 10-fold further dose-dependent increases in NT content are produced by forskolin, with maximal effects at forskolin concentrations of 0.25 to $1.0 \times 10^{-6} \mathrm{M}$ (Fig. 3).

In cultures treated with NGF plus dexamethasone, cellular content of NT increases rapidly during the first week of treatment and then plateaus or rises slowly for at least 2 additional weeks. During the same period, control cultures show no increases in NT content (Fig. 4). The presence of forskolin or CT in addition to NGF and dexamethasone stimulates both the rate of increase of NT content and the absolute magnitude of the increase (Fig. 5). At no time up to 4 weeks of treatment does the amount of NT in cultures with NGF plus dexamethasone approach that in cultures with NGF plus dexamethasone plus forskolin (Fig. 6). However, the combination of forskolin plus NGF is as effective as that of dexamethasone plus NGF (Fig. 5).

The regulation of NT content of $\mathrm{PC} 12$ cells is influenced by the removal of serum from the culture medium. In routine medium containing $10 \%$ horse serum and $5 \%$ fetal bovine serum without other additives, $\mathrm{PC} 12$ cells contain 0 to approximately $0.15 \mathrm{pmol} \mathrm{NT} / \mathrm{mg}$ protein, with less than $0.05 \mathrm{pmol} / \mathrm{mg}$ protein in most experiments (Figs. 4, 5; Table 1) (Tischler et al., 1982a). After 2 weeks of treatment in the same medium with saturating concentrations of NGF plus dexamethasone, the cells contain approximately $0.4-2.0 \mathrm{pmol} \mathrm{NT} / \mathrm{mg}$ protein (Figs. 1, 2, 4) (Tischler et al., 1982a). The presence of forskolin in addition to NGF plus dexamethasone further increases the content of NT after 2 weeks to $7.0-30.0 \mathrm{pmol} / \mathrm{mg}$ protein (Figs. 3,6 ). In medium with no serum, the amounts of NT in cells treated for 2 or more weeks with the same concentrations of NGF plus dexamethasone are $2-10 \times$ as high as in serum-containing medium. However, in the absence of serum the effects of these agents appear to be slower (Fig. 4).

The regulation of NT content by NGF plus dexamethasone in PC12 cells treated with AraC is comparable to that in untreated cells, indicating that cell replication is not required for these agents to exert their effects (data not shown). Similarly, cells grown in vivo and then transferred to cell cultures respond to NGF plus dexamethasone comparably to cells grown continuously in culture (Table 1). 


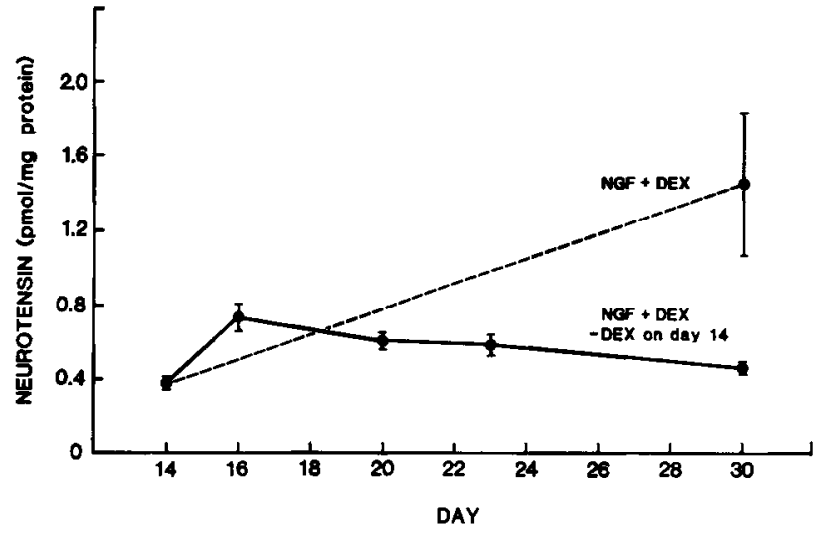

Figure 7. Effects of removing dexamethasone from cultures pretreated for $14 \mathrm{~d}$ both with dexamethasone $(1 \mu \mathrm{M})$ plus NGF $(200 \mathrm{ng} / \mathrm{ml})$. Values represent means \pm SEM of three dishes.

The effects of forskolin and dexamethasone in cultures treated with NGF are either very slowly reversible or irreversible. When forskolin is removed from cultures treated for $14 \mathrm{~d}$ with NGF plus dexamethasone and forskolin, NT content remains at or above day 14 levels for at least 2 more weeks (Fig. 6). When dexamethasone is removed from cultures treated for $14 \mathrm{~d}$ with NGF plus dexamethasone, NT content similarly remains at or above day 14 levels for at least another $16 \mathrm{~d}$ (Fig. 7).

NT is secreted from PC12 cells in response to depolarization with $52 \mathrm{mM} \mathrm{K} \mathrm{K}^{+}$, and this effect is blocked in the presence of 2 $\mathrm{mm} \mathrm{Co}{ }^{2+}$. More than half of the stimulated release of NT occurs within the first 15 min of exposure to $\mathrm{K}^{+}$, and the rate of release thereafter declines. Less than $10 \%$ of the total cellular stores of NT is released during a 30 or $60 \mathrm{~min}$ period (Fig. 8). In contrast to $\mathrm{K}^{+}$, monensin causes little or no detectable secretion of NT or depletion of cellular NT stores (Fig. 8).

\section{Discussion}

We have demonstrated that NGF, dexamethasone, and activators of adenylate cyclase act cooperatively to increase the content of NT in PCl2 cells. The increases produced by these agents are quite stable, persisting for at least 2 weeks after removal of dexamethasone or forskolin. At least some of the NT storage is likely to be in the form of secretory granules, since secretion studies suggest $\mathrm{Ca}^{2+}$-dependent release in the presence of depolarizing concentrations of $\mathrm{K}^{+}$. There may, however, be more than one type of granule, or there may be a sizable nongranular pool, since NT storage persists after lysis of catecholamine-containing granules with monensin. The cooperativity of NGF and dexamethasone has been reported previously (Tischler et al., 1982a, 1983b). The additional data relating to stability of NT stores, to NT secretion, and to cAMP are new findings.

A number of experimental models currently exist in which production or storage of neuropeptides in vitro is governed by NGF, corticosteroids, or cAMP. NGF increases the content of substance $\mathrm{P}$ in immature sensory ganglia (Otten et al., 1982). Glucocorticoids increase the production or storage of NT (Zeytinoglu et al., 1983) and calcitonin (Rosenfeld et al., 1983) in rat medullary thyroid carcinoma cells, of growth hormone in rat pituitary tumor cells (Evans et al., 1982), and of enkephalin in mouse neuroblastoma $\times$ rat glioma hybrids (Glaser et al., 1981). Cyclic AMP increases the content of vasoactive intestinal peptide in normal adult bovine chromaffin cells (Eiden and Hotchkiss, 1983). PC12 cells, however, appear to be a unique experimental model in that NGF, corticosteroids, and cAMP all act together to increase NT stores. Comparable cooperative regulation by multiple different agents very likely also affects the differentiation, maturation, and function of normal chro-

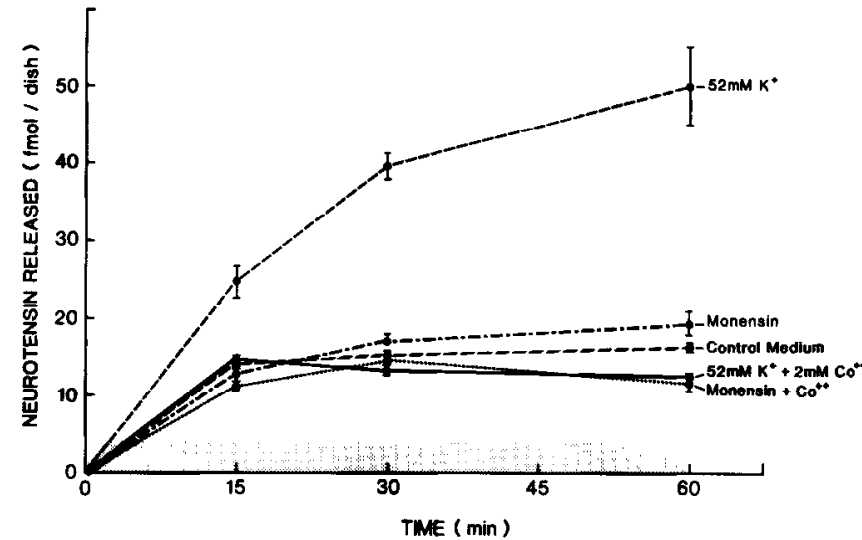

Figure 8. Time course for stimulated release of NT from PC12 cells maintained for $24 \mathrm{~d}$ with dexamethasone $(1 \mu \mathrm{M})$ plus NGF $(200 \mathrm{ng} / \mathrm{ml})$. The detection limit of the radioimmunoassay was $3.5 \mathrm{fmol} / \mathrm{dish}$. The cells in the control incubation medium at 30 min contained $241 \pm 14$ $\mathrm{fmol} \mathrm{NT/dish}(0.40 \pm 0.02 \mathrm{pmol} / \mathrm{mg}$ protein), while those in medium with $52 \mathrm{mM} \mathrm{K} \mathrm{K}^{+}$contained $247 \pm 21 \mathrm{fmol} /$ dish and those in monensin $198 \pm 11 \mathrm{fmol} / \mathrm{dish}$. The changes in cellular content of NT were not statistically significant. Additional dishes incubated for $30 \mathrm{~min}$ in incubation medium with monensin and then washed and returned to tissue culture medium with dexamethasone plus NGF for $12 \mathrm{hr}$ showed a small decrease in NT content per dish compared to similarly treated control cultures [ $228 \pm 17$ vs. $168 \pm 12 \mathrm{fmol} /$ dish $(p<0.05)]$ but no decrease per milligram of protein. The decrease per dish therefore probably resulted from detachment of some cells in the monensin-treated cultures. Values represent means \pm SEM of three dishes.

maffin cells and other neural-crest-derived cells in vivo. Studies of NT regulation in PC12 cells might provide insights into cellular and molecular mechanisms underlying these normal regulatory events, and into ways in which regulatory mechanisms might become deranged during the development of tumors.

As in the case of PC12 cells, phenotypic expression in chromaffin cells, which are normal counterpart of PC12 cells, is known to be influenced by NGF, glucocorticoids, and cAMP (Landis and Patterson, 1981; Unsicker et al., 1978, 1980). The precise effects of these agents, alone or in combination, might vary at different periods in lifc. Exposure of immature chromaffin cells to NGF can transform these cells into sympathetic neurons in vivo (Aloe and Levi-Montalcini, 1979) or in vitro (Unsicker et al., 1978). In adult chromaffin cells, NGF might play a role in regulating catecholamine production (Otten et al., 1977). Glucocorticoids and cAMP might counteract the effects of NGF during development (Landis and Patterson, 1981; Unsicker et al., 1978, 1980) and regulate catecholamine synthesis in adult life (Tischler et al., 1982b). Normal chromaffin cells in vivo are exposed to high concentrations of glucocorticoids from the surrounding adrenal cortex. Concentrations of cAMP in normal chromaffin cells might be regulated by innervation (Tischler et al., 1985; Walicke and Patterson, 1981) and by circulating hormones. Some evidence suggests that the adrenal

Table 1. Effects of NGF plus dexamethasone on $\mathrm{PC12}$ cells derived from tumors

NT concentration (pmol/mg protein) $\mathrm{NGF}(200 / \mathrm{ng} / \mathrm{ml})+$ dexamethasone

No additives

$\left(10^{-6} \mathrm{M}\right)$

Day 0

$0.10 \pm 0.02$ $-$

Day 14

$0.13 \pm 0.02$

$0.53 \pm 0.10$ 
medulla itself might be able to produce NGF (Harper et al., 1976).

An additional possible mechanism for regulating neuropeptide stores in chromaffin cells might involve protein phosphorylation by protein kinase $C$ (Pruss et al., 1985). It has recently been reported that the phorbol ester 12-O-tetradecanoylphorbol 13-acetate (TPA), an activator of protein kinase C, can specifically elevate stores of vasoactive intestinal peptide in cultures of dissociated bovine chromaffin cells (Pruss et al., 1985). In additional preliminary studies we have found no increases in the NT content of PC12 cells treated with $10^{-7} \mathrm{M}$ TPA for $4 \mathrm{~d}$ or for $7 \mathrm{~d}$, either alone or in combination with NGF (A. S. Tischler, Y. C. Lee, W. J. Jason, and S. R. Bloom, unpublished observations).

The biosynthesis of neuropeptides generally involves the formation of large precursor molecules, which are then processed to yield the final secretory products by a series of posttranslational modifications (Rosenfeld et al., 1983). Environmental influences that regulate NT content in PC12 cells might do so at the transcriptional level, by affecting initiation or rate of transcription. Alternatively, they might act at a posttranscriptional level to increase the conversion of a precursor that is not detected in our radioimmunoassay into a product that is detectable. Other possibilities are that they might prevent degradation of NT or of NT mRNA. Experiments with actinomycin $\mathrm{D}$, a transcription inhibitor, suggest that both NGF and dexamethasone act by increasing transcription (Tischler et al., 1983b). The protracted time courses for the effects of forskolin or CT suggest that these agents also affect transcription. It is of interest, however, that we have been unable to detect a high-molecularweight NT precursor in PC1 2 cells chromatographically (Tischler et al., 1982a). It remains to be determined whether this reflects the scarcity of such a precursor, its instability under the harvesting conditions we employ, or its inability to be detected by the antibody in our radioimmunoassay. We have also been unable to immunoprecipitate a precursor of NT from cell-free translations of PC12 ccll mRNA (A. S. Tischler and R. Goodman, unpublished observations).

The additivity of the effects of NGF, dexamethasone, and cAMP on NT content suggests that these agents act by different mechanisms. The mechanism of action of NGF in general is unknown, but NGF appcars to exact a permissive effect on NT regulation, facilitating the actions of dexamethasone or activators of adenylate cyclase (Fig. 5). A possibly analogous situation exists for cultured pituitary tumor cells, in which tri-iodothyronine and dexamethasone each independently increases transcription of the growth hormone gene and together produce an increase greater than that induced by either agent alone (Evans et al., 1982). It remains to be determined to what extent this analogy is valid for NT increases in PC12 cells. One of the effects of NGF on PC12 cells is to promote outgrowth of neurite-like processes (Greene and Tischler, 1976, 1982), and it could be hypothesized that NGF might cause increases in NT content merely because these processes serve as a reservoir for NT. It is clear that this is not the case, however, because NT content is regulated comparably in monolayer cultures and in spinner cultures (Tischler et al., 1982a). Under the latter conditions the cells do not form processes (Tischler et al., 1983a). Further, process outgrowth is less extensive in the presence of NGF plus forskolin or CT than in the presence of NGF alone. It is possible, however, that some of the serum-related variations in magnitude and time courses of NT increases might be attributable to differences in extent of process outgrowth in different serum lots.

Glucocorticoids induce growth hormone and other peptides by binding directly to portions of the involved genes (Rosenfeld et al., 1983). This mechanism might also pertain to regulation of NT content in PC1 2 cells. However, the possibility of indirect effects has not been ruled out. One possible means by which dexamethasone might indirectly influence NT stores is through its effects on catecholamine storage. Dexamethasone induces 2to 3-fold increases in catecholamine storage in PC12 cells (Tischler et al., 1983c). Evidence from some studies of normal bovine chromaffin cells suggests that increased concentrations of catecholamines in an extragranular cytosolic pool can inhibit enzymes that degrade enkephalin precursors in those cells (Caffrey and Hodges, 1982), and it is possible that comparable mechanisms could regulate NT content in PC12 cells. Other investigations, however, show increased synthesis and processing of enkephalin precursors in normal chromaffin cells after catecholamine depletion (Wilson et al., 1980, 1984). In additional preliminary studies we have found that treatment of $\mathrm{PC} 12$ cells with $10^{-5} \mathrm{M}$ reserpine almost totally depletes catecholamine stores (Greene and Rein, 1977) either before or after exposure to NGF plus dexamethasone and forskolin leads to no changes or to small decreases in NT stores (A. S. Tischler, Y. C. Lee, and S. R. Bloom, unpublished observations). Indirect effects on catecholamine stores are therefore likely to constitute at most only a minor component of the glucocorticoid-mediated increase in NT stores.

Forskolin and CT both act by increasing intracellular concentrations of cAMP. Forskolin acts directly on the catalytic subunit of adenylate cyclase (Seamon and Daly, 1983), while CT acts indirectly by modifying the regulatory GTP-binding subunit (Spiegel et al., 1985). Because the two drugs increase cAMP concentrations by different mechanisms but produce comparable effects on NT content, it is likely that their effects on NT content are mediated by cAMP rather than by unanticipated mechanisms. Both agents can produce greater increases in cAMP stores than those achieved with exogenous dibutyryl or 8-bromocyclic AMP, and these increases can be several hundred fold or greater in PC12 cells (Rabe et al., 1982). Forskolin or 8-bromocyclic AMP have been shown to cause small increases in synthesis and processing of enkephalin precursors in cultures of normal bovine chromaffin cells (Wilson ct al., 1984). The mechanism of these effects is unknown. Forskolin or cAMP, however, are known to stimulate transcription of the prolactin gene in rat pituitary tumor cells by a mechanism that might involve phosphorylation of specific chromatin-associated proteins (Murdock et al., 1982). In appropriate concentrations, these agents or CT can also increase stores of dopamine in normal bovine chromaffin cells (Wilson et al., 1984) or in PC12 cells (Tischler et al., 1983c). Our finding of a higher content of NT in PC12 cells treated with dexamethasone plus NGF in the absence than in the presence of serum might be related to the fact that serum can depress intracellular cAMP in neural cells in vitro (Kessler et al., 1984). However, our finding might also be due in part to differences in protein content per cell in serumfree and serum-containing cultures.

NT is released from PC12 cells in response to depolarizing concentrations of $\mathrm{K}^{+}$, and this release is blocked in the presence of $\mathrm{Co}^{2+}$, a calcium channel blocker (Hagiwara and Byerly, 1981). These findings suggest that $\mathrm{K}^{+}$-stimulated release of NT occurs via calcium-dependent exocytosis, similarly to release of catecholamines and other neuropeptides from normal chromaffin cells and other neuroendocrine cells. $\mathrm{Ca}^{2+}$-dependent release of neurotensin has also been demonstrated in the rat brain (Iversen et al., 1978). The time course of $\mathrm{K}^{+}$-stimulated NT release from PC12 cells resembles that of catecholamine release under the same conditions (Greene and Rein, 1977) but is somewhat more prolonged. While NGF-treated PC12 cells release about $10 \%$ of their total catecholamine stores in the presence of $52 \mathrm{mM} \mathrm{K} \mathrm{K}^{+}$ (Greene and Rein, 1977), a negligible fraction of total NT stores is released. The time courses of catecholamine and NT release and the percentages of cellular stores released might reflect both inactivation of calcium channels (Hagiwara and Byerly, 1981) 
and the proportions of catecholamines or of NT in releasable pools. Substances that are released by exocytosis are stored in secretory granules in neuroendocrine cells. Treatment of PC12 cells or of normal chromaffin cells with the ionophore monensin results in intracellular lysis of secretory granules, and in virtually complete depletion of catecholamines within $30 \mathrm{~min}$ (Geisow and Burgoyne, 1982; Perlman et al., 1982). This depletion presumably results from rapid enzymatic degradation of catecholamines as they are released into the cytosol from lysed granules (Perlman et al., 1982). We treated PC12 cells with monensin to determine whether NT stores would be similarly affected and found little or no effect (Fig. 8). A small amount of NT release and depletion that began after $30 \mathrm{~min}$ in monensin may have resulted from toxicity or from other mechanisms. The compartmentalization of storage of $\mathrm{NT}$ in $\mathrm{PCl} 2$ cells thus remains unclear. Possibilities are that most of the storage is not in secretory granules, that NT is stored in a subpopulation of monensin-resistant granules, or that degradation of NT released by granule lysis is relatively slow. The fact that cells treated with monensin for 30 min show no depletion of NT stores after being returned to tissue culture medium for $12 \mathrm{hr}$ argues against the last possibility.

An interesting finding in the present study is the irreversibility or very slow reversibility of increases in NT content that are promoted by forskolin in the presence of dexamethasone plus NGF or by dexamethasone in the presence of NGF (Figs. 6, 7). It is not known whether this stability of NT stores reflects stability of NT mRNA and of enzymes involved in NT synthesis, or whether it reflects a low rate of turnover of NT stores. In unstimulated cultures of normal bovine chromaffin cells, however, 10-14\% of enkephalin stores appear to be synthesized de novo in a 3-d period (Wilson et al., 1984). If rate of synthesis is related to rate of turnover, and if turnover of NT in PC12 cells is comparable to that of enkephalin in normal chromaffin cells, then a $50-70 \%$ turnover of NT should have occurred during the 14-d periods after the removal of forskolin or dexamethasone. This would suggest that stability of forskolin- or dexamethasone-associated increases in NT stores is not attributable to a low rate of turnover. Since PC12 cells treated with NGF do not divide (Greene and Tischler, 1976), the long-term increases in NT content in these cells in response to forskolin or dexamethasone might reflect mechanisms by which individual neurons or chromaffin cells become committed to a particular transmitter phenotype during normal development. A practical implication of the stability of $\mathrm{NT}$ levels in PC12 cells is that studies designed to test the effects of corticosteriods or other agents on the content of neuropeptides or catecholamines in primary cultures of normal chromaffin cells might need to be conducted over a very long period.

The fact that PC12 cells grown in vivo contain very little NT is paradoxical. These cells contain greater amounts of NE than their counterparts grown in vitro with NGF and other additives (Greene and Tischler, 1976) and more closely resemble normal NE-containing chromaffin cells. Since normal NE cells in vivo are known to contain NT (Rokaeus et al., 1982), PC12 cells might be expected a priori to contain more NT in vivo than in vitro. However, $\mathrm{PC1} 2$ cells grown in vivo differ from normal $\mathrm{NE}$ cells in that they are in a subcutaneous location where they are not subject to influences of adrenal cortical steroids and they are not innervated. The low concentration of NT in PC1 2 cells grown in vivo despite the cells' high NE content is consistent with other data indicating that catecholamines and neuropeptides in pheochromocytoma cells can be regulated separately (Tischler et al., 1984).

\section{References}

Aloe, L., and R. Levi-Montalcini (1979) Nerve growth factor induced transformation of immature chromaffin cells in vivo into sympathetic neurons: Effect of antiserum to nerve growth factor. Proc. Natl. Acad. Sci. USA 76: 1248-1250.

Bornstein, M. G. (1958) Reconstituted rat-tail collagen used as a substrate for tissue cultures on coverslips in Maximow slides and roller tubes. Lab. Invest. 7: 134-137.

Bradford, M. M. (1976) A rapid and sensitive method for the quantitation of microgram quantities of protein utilizing the principle of protein-dye binding. Anal. Biochem. 72: 248-254.

Caffrey, J. L., and D. H. Hodges (1982) Inhibition of the enzymatic degradation of net-enkephalin by catecholamines. Endocrinology 110 : 291-293.

Carraway, R., and S. E. Leeman (1973) The evaluation of a new hypotensive peptide, neurotensin, from bovine hypothalamic. J. Biol. Chem. 248: 6854-6861.

Eiden, L. E., and A. J. Hotchkiss (1983) Cyclic adenosine monophosphatc rcgulates vasoactive intestinal polypeptide and enkephalin biosynthesis in cultured bovine chromaffin cells. Neuropeptides 4 : $1-9$.

Evans, R. M., N. C. Birnberg, and M. G. Rosenfeld (1982) Glucocorticoid and thyroid hormones transcriptionally regulate growth hormone gene expression. Proc. Natl. Acad. Sci. USA 79: 7659-7663.

Geisow, M. J., and R. D. Burgoyne (1982) Effect of monensin on chromaffin cells and the mechanism of organelle swelling. Cell Biol. Int. Rep. 6: 933-939.

Glaser, T., K. Hübner, and B. Hamprecht (1981) Glucocorticoids elevate the level of enkephalin-like peptides in neuroblastoma $\times$ glioma hybrid cells. FEBS Lett. 1431: 63-66.

Goedert, M., G. P. Reynolds, and P. C. Emson (1983) Neurotensin in the adrenal medulla. Neurosci. Lett. 35: 155-160.

Greene, L. A., and G. Rein (1976) Synthesis, storage and release of acetylcholine by a noradrenergic pheochromocytoma cell line. Nature 268: 349-351.

Greene, L. A., and G. Rein (1977) Release, storage and uptake of catecholamines by a clonal line of nerve growth factor responsive pheochromocytoma cells. Brain Res. 129: 247-263.

Greene, L. A., and A. S. Tischler (1976) Establishment of a noradrenergic clonal line of rat adrenal pheochromocytoma cells which respond to nerve growth factor. Proc. Natl. Acad. Sci. USA 73: 2424 2428.

Greene, L. A., and A. S. Tischler (1982) PC12 pheochromocytoma cultures in neurobiological research. In Advances in Cellular Neurobiology, S. Fedoroff and L. Hertz, eds., p. 373, Academic, New York.

Hagiwara, S., and L. Byerly (1981) Calcium channel. Annu. Rev. Neurosci. 4: 69-125.

Harper, G. P., F. L. Pearse, and C. A. Vernon (1976) Production of nerve growth factor by the mouse adrenal medulla. Nature $261: 251-$ 253.

Henry, J. L. (1982) Electrophysiological studies on the neuroactive properties of neurotensin. Ann. NY Acad. Sci. 400: 216-227.

Iversen, L. L., S. D. Iversen, F. Bloom, C. Douglas, M. Brown, and W. Vale (1978) Calcium-dependent release of somatostatin and neurotensin from rat brain in vitro. Nature $273: 161-163$.

Kessler, J. A., D. C. Spray, J. C. Saez, and M. V. L. Bennett (1984) Determination of synaptic phenotype: Insulin and cyclic AMP independently initiate development of electrotonic coupling between cultured sympathetic neurons. Proc. Natl. Acad. Sci. USA 81: 62356239.

Landis, S.C., and P. H. Patterson (1981) Neural crest cell lineages. Trends Neurosci. 7: 172-175.

Lee, Y. C., J. M. Allen, L. O. Uttenthal, M. C. Walker, J. Schemilt, S. S. Gill, and S. R. Bloom (1984) The metabolism of intravenously infused neurotensin in man and its chromatographic characterization in human plasma. J. Clin. Endocrinol. Metab. 59: 45-50.

Leeman, S. E., and R. E. Carraway (1982) Neurotensin: Discovery, isolation, characterization, synthesis and possible physiological roles. Ann. NY Acad. Sci. 400:1-16.

Mobley, W. C., A. Schenker, and E. M. Shooter (1976) Characterization and isolation of proteolytically modified nerve growth factor. Biochemistry 15: 5543-5551.

Murdock, G. H., M. G. Rosenfeld, and R. M. Evans (1982) Eukaryotic transcriptional regulation and chromatin-associated protein phosphorylation by cyclic AMP. Science 218: 1315-1317.

Otten, U., M. Schwab, C. Gagnon, and H. Thoenen (1977) Selective induction of tyrosine hydroxylase and dopamine B hydroxylase by nerve growth factor: Comparison between adrenal medulla and sympathetic ganglia of adult and newborn rats. Brain Res. 133: 291-303. 
Otten, U., M. Pack-Burnett, F. Businger, and H. P. Lorez (1982) Nerve growth factor regulates peptide content in primary sensory neurons. Soc. Neurosci. Abstr. 8: 110.10 .

Perlman, R. L., B. E. Sheard, A. S. Tischler, and P. W. L. Kwan (1982) Monensin depletes PC12 cells of catecholamines and of chromaffintype granules. Neurosci. Lett. 29: 177-182.

Polak, J. M., and S. R. Bloom (1982) The central and peripheral distribution of neurotensin. Ann. NY Acad. Sci. 400: 75-83.

Pruss, R. M., J. R. Moskal, L. E. Eiden, and M. C. Beinfeld (1985) Specific regulation of VIP biosynthesis by phorbol ester in bovine chromaffin cells. Endocrinology 117: 1020-1026.

Rabe, C. S., J. E. Schneider, and R. McGee, Jr. (1982) Enhancement of depolarization-dependent ncurosecretion from PC12 cells by forskolin-induced elevation of cyclic AMP. J. Cyclic Nucleotide Res. 8: 371-384.

Rokaeus, A. G., G. Fried, and J. M. Lundberg (1982) Neurotensinlike immunoreactivity (NTLI) in the adrenal medulla. Localization, quantitation, characterization, subcellular fractionation and release upon splanchnic nerve activation. Ann. NY Acad. Sci. 400: 389-391.

Rokaeus, A. G., G. Fried, and J. M. Lundberg (1984) Occurrence, storage and release of neurotensin-like immunoreactivity from the adrenal gland. Acta Physiol. Scand. 120: 373-380.

Rosenfeld, M. G., S. G. Amara, N. C. Birnberg, J-J. Mermod, G. H. Murdock, and R. M. Evans (1983) Calcitonin, prolactin and growth hormone gene regulation as model systems for the characterization of neuroendocrine regulation. Rec. Prog. Horm. Res. 39: 305-351.

Schultzbcrg, M., T. Hökfelt, G. Nilsson, L. Terenius, J. F. Rehfeld, M. Brown, R. Elde, M. Goldstein, and S. Said (1980) Distribution of peptide- and catecholamine-containing neurons in the gastrointestinal tract of rat and guinea pig. Immunohistochemical studies with antisera to substance $P$, vasoactive intestinal polypeptide, enkephalins, somatostatin, gastrin/cholecystokinin, neurotensin and dopamine B-hydroxylase. Neuroscience 5: 689-744

Seamon, K. B., and J. W. Daly (1983) Forskolin, cyclic AMP, and cellular physiology. Trends Pharmacol. Sci. 4: 120-123.

Spector, T. (1978) Refinement of the Coomassie blue method of protein quantitation. Anal. Biochem. 86: 146-156.

Spiegel, A. M., P. Gierschick, M. A. Levine, and R. N. Downs (1985) Clinical implications of guanine nucleotide-binding proteins as receptor-effector couplers. N. Engl. J. Med. 312: 26-33.

Sundler, F., R. Hakanson, S. Leander, and R. Uddman (1982) Light and electron microscopic localization of neurotensin in the gastrointestinal tract. Ann. NY Acad. Sci. 400: 94-104.

Terenghi, A., J. M. Polak, I. M. Varndell, Y. C. Lee, J. Wharton, and S. R. Bloom (1982) Neurotensin-like immunoreactivity in a subpopulation of noradrenaline-containing cells of the cat adrenal gland. Endocrinology 112: 226-233.

Tischler, A. S., Y. C. Lee, V. W. Slayton, and S. R. Bloom (1982a) Content and release of neurotensin in $\mathrm{PC} 12$ pheochromocytoma cell cultures: Modulation by dexamethasone and nerve growth factor. Reg. Peptides 3: 415-421.

Tischler, A. S., R. L. Perlman, G. Nunnemacher, G. M. Morse, R. A. DeLellis, and H. J. Wolfe (1982b) Long-term effects of dexamethasone and nerve growth factor on adrenal medullary cells cultured from young adult rats. Cell Tissue Res. 225: 525-542.

Tischler, A. S., L. A. Greene, P. W. Kwan, and V. W. Slayton (1983a) Ultrastructural effects of nerve growth factor on PC1 2 pheochromocytoma cells in spinner culture. Cell Tissue Res. 228: 641-648.

Tischler, A. S., Y. C. Lee, V. W. Slayton, and S. R. Bloom (1983b) Kinetics of regulation of neurotensin content in PC12 cells. Life Sci. 33: 347-351

Tischler, A. S., R. L. Perlman, G. M. Morse, and B. E. Sheard (1983c) Glucocorticoids increase catecholamine synthesis and storage in $\mathrm{PC} 12$ pheochromocytoma cell cultures. J. Neurochem. 40:364-370.

Tischler, A. S., Y. C. Lee, V. W. Slayton, D. Costopoulos, R. L. Perlman, and S. R. Bloom (1984) Production of "ectopic" vasoactive intestinal peptide-like and neurotensin-like immunoreactivity in human pheochromocytoma cell cultures. J. Neurosci. 4: 1398-1404.

Tischler, A. S., R. L. Perlman, J. E. Jumblatt, D. Costopoulos, and J. R. Horwitz (1986) Vasoactive intestinal peptide activates tyrosine hydroxylase in cultures of normal and neoplastic chromaffin cells. In Neural and Endocrine Peptides and Receptors, T. Moody, ed., Plenum, New York.

Unsicker, K. B., B. Krisch, U. Otten, and H. Thoenen (1978) Nerve growth factor-induced fiber outgrowth from isolated rat adrenal chromaffin cells: Impairment by glucocorticoids. Proc. Natl. Acad. Sci. USA $75: 3498$.

Unsicker, K., B. Rieffert, and W. Ziegler (1980) Effects of cell culture conditions, nerve growth factor, dexamethasone and cyclic AMP on adrenal chromaffin cells in vitro. In Histochemistry and Cell Biology of Autonomic Neurons, SIF Cells and Paraneurons, O. Eränkö, S. Soinila, and H. Päivärinta, eds., p. 59, Raven, New York.

Walicke, P. A., and P. H. Patterson (1981) On the role of cyclic nucleotides in the transmitter choice made by sympathetic neurons. J. Neurosci. 1: 333-342.

Warren, S. W., and R. N. Chute (1972) Pheochromocytoma. Cancer 19: 327-331.

Wilson, S. P., K-J Chang, and O. H. Viveros (1980) Synthesis of enkephalins by adrenal medullary chromaffin cells: Reserpine increases incorporation of radiolabelled amino acids. Proc. Natl. Acad. Sci. USA 77: 4364-4368.

Wilson, S. P., C. D. Unswerth, and O. H. Viveros (1984) Regulation of opioid peptide synthesis and processing in adrenal chromaffin cells by catecholamines and cyclic adenosine $3^{\prime}: 5^{\prime}$-monophosphate. $\mathrm{J}$. Neurosci. 4: 2993-3001.

Zeytinoglu, F., N. P. Brazeau, and C. Mougin (1983) Regulation of neurotensin secretion in a mammalian C-cell line: Effect of dexamethasone. Reg. Peptides 6: 147-154. 